\title{
MANHAJ TARBIYAH OF KH. ABD. RAHMAN AMBO DALLE AS A RELIGIOUS MUSLIM LEADER IN THE BUGIS COMMUNITY IN SOUTH SULAWESI
}

\author{
Mansur \\ STAI DDI Sidenreng Rappang \\ Jalan Tugu Tani Majelling Watang Kabupaten Sidenreng Rappang \\ Email: mansurahmad1965@gmail.com
}

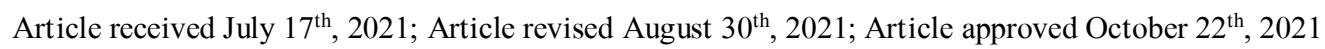

\begin{abstract}
This study aims to explain the Manhaj of education, one of the leading Islamic educators in South Sulawesi named KH. Abd. Rahman Ambo Dalle. Manhaj, in this study, generally means thinking; in this case, it focuses on the style of educational thought that has been carried out by KH. Abd. Rahman Ambo Dalle as long as his act in fostering and leading educational institutions. The aim was to explain the thoughts and development system of Islamic education, as well as the specific principles applied by KH. Abd. Ambo Dalle starts from basic education and Islamic higher education, which is the development of thoughts and methods that have been contributed by previous educators. The results showed that KH. Abd. Rahman Ambo Dalle implemented 4 Manhaj Tarbiyah, namely Manhaj Tarbiyah Al-Aqaid, Manhaj Tarbiyah Al Akhlak, Manhaj Tarbiyah Al Mutaallim, and Manhaj Tarbiyah Al Tullab with its own characteristics in the implementation. The relevance of the fourth Manhaj Tarbiyah in its journey has several adjustments that allow future generations to critique and filter the values that were appropriate before but maybe considered irrelevant today.
\end{abstract}

Keywords: manhaj tarbiyah, islamic education, lontara bugis.

\section{INTRODUCTION}

$\mathrm{E}$ ducation has become an obligation for mankind, especially for Muslims, because education is the duty of the Apostles. Prophet Muhammad SAW. As a follow-up as well as a role model for every educator, this task always needs to be preserved until the end of life.

Educators or educating not only have enthusiasm but the right Manhaj is needed. Even educators must be carried out with deep scientific disciplines because educators without knowledge will be dangerous, can damage humans in general and especially the students themselves. The damage to these students not only endangers students personally but can result in damaging others, damaging the nation.

In discussing the discourse of Islamic education thought, both traditional and modern, we cannot forget one name from the many famous names of educators, namely, KH. Abd. Rahman Ambo Dalle, especially the people of South Sulawesi. His thoughts and intelligent actions are always based on the texts of the Qur'an and Al-Hadith of the Prophet Muhammad, so that many people follow him and make reference to his works, especially dealing with current life problems.

KH. Abd. Rahman Ambo Dalle is a figure of an Ulama who never gets tired of restoring the identity of Muslims in Indonesia, especially in Sulawesi. There have been many tips that have been carried out, including continuously spreading Islamic education thoughts that do not deviate from Islamic teachings.

KH. Abd. Rahman Ambo Dalle is a person who is diligent in education and is very concerned about education. It is known that in South Sulawesi, there has been an upheaval in DI/TII. Although Kahar Muzakkar was kidnapped and taken to the forest as a legal expert, but still devotes his attention to education. This can be proven after returning to the forest, immediately joining with friends to establish, foster educational institutions, and have previously been active together in Darud Da'wah Wal Irsyad (DDI) institutions or organizations.

Manhaj, in this study, generally means thinking; in this case, it focuses on the style of educational thought that has been carried out by KH. Abd. Rahman Ambo Dalle 
as long as he fosters and leads educational institutions. The aim is to explain the thoughts and development system of Islamic education, as well as the specific principles applied by KH. Abd. AMBO DALLE starts from basic education and Islamic higher education, which is the development of thoughts and methods that have been contributed by previous educators.

In writing the curriculum vitae of $\mathrm{KH}$. Abd. Rahman Ambo Dalle by the author was still quite easy, and this is due to several factors. First: some of my friends are still alive even though they have been gone to the unseen world for a long time. Second: $\mathrm{KH}$. Abd. Rahman Ambo Dalle is a scholar who is creative and productive because of the many writings that he finds. Third: Close family, his children, are still alive.

KH. Abd. Rahman Ambo Dalle, an Ulama who is descended from noble blood, was born from a husband and wife, Daeng Patobo, with Andi Cenra Dewa. He was born in Ujungnge Village, Tanah Sitolo Subdistrict, a sub-district located north of Sengkang, the capital city of Wajo Regency, in 1900 (Arrosi 1993).

Abd. Muiz Kabry 2000 describes the daily activities of KH. Abd. Rahman Ambo Dalle, where his parents trained him with religious education, was entrusted with studying the Qur'an at his aunt's house, then returned to his parents (mother) to continue studying the Qur'an. After completing the basic teaching of the Qur'an, he continued his study of the Qur'an (advanced study) to one of the scholars of H.M. Isaac in Tancung, Wajo Regency (Muiz 2000)

When KH. Abd. Rahman Ambo Dalle reached school age (adolescence) and spent a lot of time seeking and gaining knowledge, both religious knowledge and general sciences. Arman Arroissi 1993 explained that Ambo Dalle did not have too many opport unities outside the home because, in the morning, he had to study at the Volks School (Sekolah Rakyat). The rest is to understand various kinds of religious knowledge. $\mathrm{KH}$. Abd. Rahman Ambo Dalle deepened his religious knowledge at Madrasah Arabiyah Islamiyah (MAI) in Sengkang. By KH. Moh. As'ad acknowledged the perseverance, intelligence of KH. Abd. Rahman Ambo Dalle so appointed as a personal assistant (Arrosi 1993).
Madrasah Arabiyah Islamiyah (MAI) Sengkang by the people of South Sulawesi recognizes it as a quality educational institution so that many people glance at it even though it is far away, for example, King Soppeng Riaja is of the view that at Madrasah Arabiyah Islamiyah (MAI) Sengkang has produced many religious scholars, one of which is Madrasah Arabiyah Islamiyah (MAI) Sengkang. Among them, the most well known is the personal secretary of KH. Moh. As'ad.

Arman Arrosi 1993 explained that the Soppeng Riaja kingdom sent a delegation so that KH. Moh. As'ad sent a teacher who could establish and lead the same Madrasah in Mangkoso. At first, KH. Moh. As'ad objected. However, after being urged many times and coincidentally the wife of KH. Abd. Rahman Ambo Dalle came from Soppeng Riaja, finally KH. Moh. As'ad gave up his beloved Urid and assistant to go to Mangkoso (Arrosi 1993).

The existence of KH. Abd. Rahman Ambo Dalle in Mangkoso with friends from Madrasah Arabiyah Islamiyah (MAI) Sengkang gave birth to a brilliant idea to form an Islamic organization through the cleric Ahlusunnah Wal-Jamaah, South Sulawesi, this idea was implemented in Watang Soppeng.

The Ulama's Deliberation in Watang Soppeng was held on Wednesday 5 February 1947 AD, coinciding with 14 Rabiul Awal $1366 \mathrm{H}$. For three days. The results of the deliberation agreed on the formation of an organization engaged in education, da'wah and social society, named Darud Da'wah Wal Irsyad (DDI), who was elected as chairman of KH. Abd. Rahman Ambo Dalle. Therefore, all Madrasah Arabiyah Islamiyah (MAI) under the auspices of Mangkoso were integrated into the Darud Da'wah Wal Irsyad (DDI) organization (Azhar Arsyad 2003)

Concepts of thought, systems, and methods of Islamic education are theoretically used as the basic basis for describing the education Manhaj KH. Abd. Rahman Ambo Dalle, who has been considered to be very rapidly developing in Indonesia today. in the discussion later, will be able to reveal the educational thoughts of $\mathrm{KH}$. Abd. Rahman Ambo Dalle, which has been considered difficult to find empirically. 


\section{RESEARCH METHOD}

This research is a descriptive study using a qualitative approach - data collection techniques through interviews, observation, and documentation. The process of determining informants by researchers must be full of consideration, especially regarding the characteristics of informants, such as differences in social status and others. (Arikunto 1993)

The observational check list was made in order to determine the themes of the problems to be studied. Check list interview was formed in the main questions that will be asked to respondents. This checklist was made in the form of a semi-structured, which was used for informational purposes in writing or orally. Thus, only two types of methods will be used to obtain data in future research, namely, the observation and interview method.

The types of data collected in the field: Interpretation; that is, the researcher looks for the broadest meaning of the answers obtained from the informants, and then the answers were linked. In interpreting the informants responses through description analysis, correlation, and the significance of the answers. Inductive; Researchers in analyzing data start from events that are specific to be subsequently drawn and set a general conclusion (Arifin 2003).

The collected data was then processed through deductive techniques starting from a public event, and then a specific conclusion was determined. Researchers analyzing the data by comparing the data or information that has been determined were also carried out for further analysis carefully to obtain precise and accurate conclusions. (Arifin 2003)

\section{DISCUSSION}

\section{Manhaj Tarbiyah Al-Aqaid}

The most crucial aspect that needs to be taught to humans is related to the problem of Al-Aqaid. The aqaid that is meant is none other than Aqaid Islamiyyah (Al-Munawwir 1997). The importance of teaching aqaid is expected to maintain the authenticity of aqidah among Muslims; Muslims continue to purify the Oneness of Allah SWT, there is no one to be worshipped but Allah SWT.

Muhammad Naquid Al-Attas 2003 explains Aqaid, which directs human faith towards worship of Allah SWT, as God Almighty who controls all creatures and sent Prophet Muhammad as a Prophet and Messenger of Allah (Al-Attas 2003)

The beliefs held by Islam are called Aqaid Islamiyah and become human nature. Worship and submission of man to Allah SWT as God Almighty never contradicts human reason. Aqaid is an understanding that wants to straighten and purify one's monotheism, unite God, and acknowledge that God has no children, as is the case with other creatures.

K.H. Abd. Rahman Ambo Dalle, who is very interested in the importance of Aqidah education, through aqidah education, humans will understand their existence as creatures and direct humans to worship God better. According to H. Muhammad Yunus Samad 2004, the gurutta in his Manhaj Tarbiyah, which occupies first and foremost, is monotheism, which is nothing but strengthening aqidah in terms of the oneness of Allah SWT (Yunus 2004).

K.H. Abd. Rahman Ambo Dalle in understanding aqidah is in line with $\mathrm{Abu}$ Hasan Al-Asy'ari, commonly known as the Ahlusunnah ideology. The Ahlusunnah sect founded by Al-Asy'ari is called the AlAsy'ariyah School, a flow of blending between the Salaf and the Mu'tazilites. Al-Ash'ari understands that naql (religious texts) is more important than reason. K.H.Abd. Rahman Ambo Dalle adheres to the understanding of Ahlusunnah Wal-Jamaah, this can be seen that during his leadership of Darud Da'wah WalIrsyad (DDI) the principle or aqidah adopted by the organization was the aqidah of Ahlusunnah Wal-Jamaah. As stated in the household budget. (Anwar, Rozak 2002)

Ahlusunnah Wal-Jamaah seen from the point of view of the term is Ahlun = Followers or adherents. Assunnah $=$ All teachings came from the Messenger of Allah. In the form of words or deeds and takrir (approval) of the Prophet.

While Al-Jamaah means:

a. Friend Congregation.

b. Al-Khulafaurrasyidin, namely $\mathrm{Abu}$ Bakr, Umar, Usman and Ali.

c. Unity of Muslims who has recognized/followed the legitimate government.

d. Assawadul A'dzami (large group) of the Muslims. 
e. The Mujtahid faith (Hanafi, Maliki, Shafi'i and Hambali).

f. Doctrine of Imam Hasan Al-Asy'ari and Abu Mansur Al-Maturidy. (Muiz 1989).

Muslims carry out the teachings of monotheism in the sense of faith, Islam, and Ihsan. The teachings of Ahlusuunnah WalJamaah version of Abu Hasan Al-Asy'ari, which become aqidah, adhere to the book of Allah (Al-Qur'an) and the Sunnah of the Prophet Muhammad, as well as those narrated by companions, Tabi'in and imams. Imam of Hadith. However, it does not deny the power of reason which is based on the texts of the Qur'an, while the views of Ahlusunnah WalJamaah reject reason in its free form. (Syarifuddin 1999).

K.H.Abd. Rahman Ambo Dalle adheres to the Book of Allah and the Hadith of the Prophet Muhammad. But also on the words of friends and Khulafaurrasyidin. It even holds fast to Ijma, to Imam Mujtahidin and the doctrines of Abu Hasan Al-Asy'ari and Abu Mansur Al-Matarudy (Hanafi 2001). Manhaj Tarbiyah K. H. Abd. Rahman Ambo Dalle in the field of aqaid through the muhadarah and muhawarah system is essentially a question and answer process (Muiz 1989).

Abd. Muiz Kabry 1989 explains that muhadarah (weton) can also be interpreted as a lecture. In this system by K. H. Abd. Rahman Ambo Dalle as a teacher (Ustadz) conducts teaching in the form of lectures, then students are allowed to ask questions that revolve around things that are not known or understood for sure. Furthermore, the teacher (Ustadz) explains that it revolves around the questions that have been asked by the students (santri). Muhawarah, the teaching system applied by K. H. Abd. Rahman Ambo Dalle by asking a group of students (santri). Each group of students must provide an explanation or answer that revolves around the teacher's question (ustadz). (Muiz 1989).

Manhaj Muhadara and Muhawarah are applied to lower classes, especially to students at the elementary school level (Madrasah Ibtidaiyah). Even in the book entitled: Arrisalat Al-Bahiyya fi Aqaid AlIslamiyyah, as explained in the introduction to the book, it only applies to students at the Tahdiriyyah level. Meanwhile, at the next level, the Manhaj Tariyyah used has begun to enter the level of analysis, understanding a verse and hadith and the words of the Ulama. This is illustrated in a book that has been compiled in Bugis language (lontara) with the title: Al-Qaul As-Sadiq fi Ma'rifatu Al-Khaliq (Ada Tongeng-Tongeng ri Annassena Pappejeppue ri puang Allah Ta'ala).

The book addresses several issues, including:

1. COMM NOM̉ AMMAR MANOA

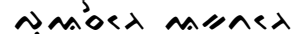

(Article about certainty in position as a creature)

2. AMヘ Neiónared

(Service section)

3. याionn $n \cos ^{2} a<\lambda$ (Dzahir's devotion)

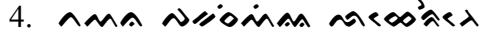
(The division of devotion is born)

5. vionin sened (The devotion of the inner form)

6. ^M^ Neióna sened (Part of inner devotion)

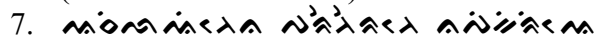
(The difference between memory and mind)

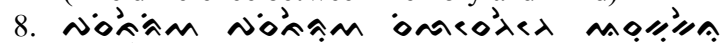

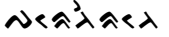

(The principles that support the perfection of memory).

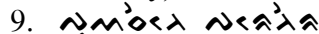

(Understanding of memory)

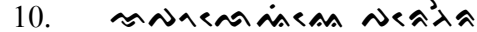
(memory position with Allah SWT)

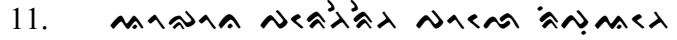
(Servant's remembrance of his Lord)

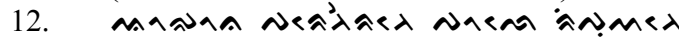
(the position of the memory of the servant)

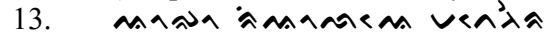
(occupied place to remember)

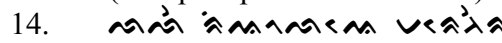
(the process of remembering)

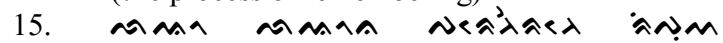
Mヘヘヘヘ

(procedures for carrying out remembrance to Allah).

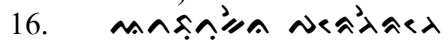
(The limit of memory ability)

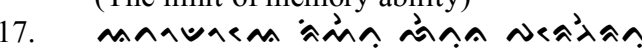
(determination of attitude when remembering)

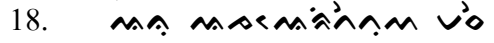
(Things that require istiqamah attitude)

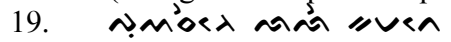

(A completeness in terms of certainty of the arrival of the time of death)

The topics discussed by K. H. Abd. Rahman Ambo Dalle was given a brief but solid argument or explanation in Bugis language. The explanation is based on verses of Qur'an and Hadith, as well as the words of Ulama (Sufism). One of the topics in the article regarding the certainty of position as a creature can be seen in: 
Sewwa Passaleng

Rilaleng Annessana Puasengnge AkkatangngE

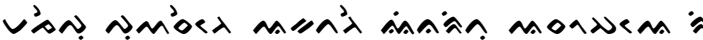
NMM MMAMM AOR MATล Minं $\lambda$ NeNOAn:.

Majeppu puang akkatangnge ianaritu assompae ri puang Allah Ta'ala nasaba atturu raptentana nennia ripappesangkana.

Makkadai Puang Allah Ta'ala ri sura Baqarah 21 : SAMA: ( DOM OiAn AMEM NV OANM NMM NTM Nmisemen Ainm Nmisi

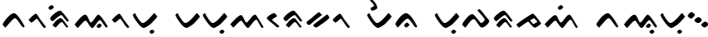
Bettuana : Hae sininna taue pada sompai puangmu puang pancajiekko nennia pancajiengngi toriolomi mamuareko menna muparajaiwi taumu.

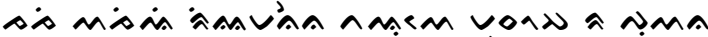

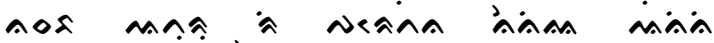

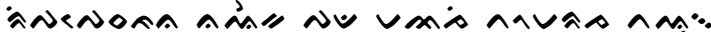
Jaji waji 'i reamanenna tauwe massompa ripanna nasaba atturu riparentana nennia annini ripappesangkana naengka pada mancaji tomaraj tau.

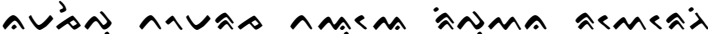

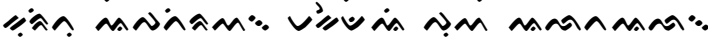

Namajeppu tomaraja taue ripuanna riwerengngi kuritu apatioang Makkadai puang Allah Ta'ala. Bettuanna: Narekko muparaiwi taumu ripang Allah Ta'ala napancajingeko menna sewwa tajang pappasara pallawengenna tongengnge, majae namadecengnge.

Aga namalomona napapole (napasilennereng) ruparupannna pakkasiwiangnge lahereng anrengnge topa baten. Namajeppu ripasilennarennai pakkasiwiang laherengnge anrengnge topa pakkasiwiang batennge iana hakikinna akkatangengnge. Nanigi-nigi lolongengngi hakikinna akkatangenge ianatu tau mejeppui alena. Nanigi-nigi majeppui alena najeppuitonitu puanna. Ianaro najello makkadana anregurutta pattasaupue. Bettuanna : Nigi-nigi majeppuiwi alena majeppu najeppuitonitu puanna.

So K. H. Abd. Rahman Ambo Dalle, in discussing problems as exemplified by choosing good Bugis words, is hard to find nowadays. Sentences that are so short but contain deep meaning.

Abd. Muiz Kabry commented on the composition of K. H. Abd. Rahman Ambo Dalle entitled Al-Qaulu As-Shodiq. The book Al-Qaulu As-Shodiq discusses the problem of monotheism with its discussion method based on the use of inner reason patterns and naql and reason. It is a book that contains clear affirmations in the field of monotheism. The main issues and sub-problems, as mentioned above by K. H. Abd. Rahman Ambo Dalle discusses it briefly and concisely accompanied by arguments. (Muiz 1976).

\section{Manhaj Tarbiyah Al-Akhlak}

One of the most important aspects to be given to humans is to educate them with moral education. Etymologically, morality comes from the Arabic plural of Khuluk, which means character, temperament, behaviour or character. The root of the word morality is khalaqa which means creating the root word Khaliq creation. It was further explained that the similarity of the roots implies that morality includes the notion of creating integration between the will of the Khaliq (God) and the behaviour of creatures (humans). A person's behaviour towards other people and their environment only contains intrinsic moral values when the action or behaviour is based on the will of Khaliq (God) (Ilyas 2002).

Thus, morality, in this sense, implies a pattern of behaviour which is a person's habit or character. The desired morality is moral that is by the will of the creator of man, namely God. Another meaning that the goodness of Allah SWT. Human beings are morals that humans themselves should carry out. Morals are not only a set of rules that humans must carry out for their fellow humans but also morals that regulate the relationship between humans and their God.

The relationship between humans and fellow humans that is very much needed is morals. The morals in question are traits embedded in the soul that encourage them to take action without the need for thought and consideration. Alternatively, at least morality form: "a trait embedded in the soul that causes various kinds of actions easily, and without the need for thought and consideration". Morals are essentially actions embedded in the human soul that can give rise to traits or actions easily without the need for consideration and thought. A person's character is an identity that can distinguish humans from other humans. Morals can also be interpreted as customs attached to a person, which causes one human being to be distinguished from another (Nata 2001).

Humans' identity from a moral point of view is at least divided into two parts: First, identity as a good human being. Second, identity as a human being is not good. Humans who have good morals are called mahmudah morals, while humans who have bad personalities are called morals of mazmumah. 
For this reason, everyone must be educated, in this case, in the concept of AlIslamiyyah tarbiyah, education with the AlIslamiyyah tarbiyah pattern, it is hoped that students can have the perfect habits desired by the hadith of the Prophet Muhammad. Above, believed to be people who believe and have good morals. K.H. Abd. Rahman Ambo Dalle is a scholar who also contributed many concepts in tarbiyah Islamiyah in the field of Al-Akhlak. According to him, morals need to be instilled in humans, excellent qualities; it is believed that humans with good and noble character will give birth to a condition that is both individually and socially that leads to happiness.

H. Muhammad Yunus Samad explained that the gurutta in his Manhaj Tarbiyah after Tawhidan then the second is moral formation. K.H.Abd. Rahman Ambo Dalle has compiled books related to morals which he calls akhlaq diniyyati. Has compiled a moral book with the title Hilyatu As-Syabab fi Ilmi Al-Akhlak Wal-Adaabi. The science of morality is the science that studies the heart's health or saves the heart. The point is the heart's health in the world, and victory is delivered the day after. K.H. Abd. Rahman Ambo Dalle in Manhaj Tarbiyah Morals that to instill morals in humans must start from childhood. It can be analyzed that the books are written are very determined for children. It is listed for students who are still sitting in Madrasah Diniyyah (SD) benches.

The things that should be introduced to children first are:

1. General character, such as:

a. Morals towards Allah SWT.

b. Morals towards the Messenger of Allah.

c. Morals towards religion.

2. Morals of a special nature such as:

a. Morals towards parents.

b. Morals towards relatives/friends.

3. More specific Adab.

General morals in question are morals that should be carried out by every human being, from children to adults, which every man and woman should carry out. Every human being is obliged to have a character to Allah SWT, morality to the Prophet Muhammad, and religion. While what is meant by special morals are morals aimed at certain objects, such as morals towards both parents, morals that are specifically aimed at children, and children towards siblings (comrades), so it only applies to friends or friends. While morals to a more specific are morals related to himself, to all members of the body or body. Humans must clean the body by bathing with water because cleaning the body will produce a healthy body, and it will make the body stronger.

Therefore, K. H. Abd. Rahman Ambo Dalle in Manhaj Tarbiyah Al-Akhlak is devoted to maintaining the body and mentions them one by one, such as etiquette towards the head and face, tongue, ears, eyes, etcetera. Islam. Such care will be able to bring benefits that are incalculable in value and bring the highest happiness.

\section{Manhaj Tarbiyah Al-Muta'lim}

Al-Mutaallim means teaching, teaching. Teachers in the community's view are seen as intelligent people, experts in the field of religion and so on (Ali 2003). Teachers who are knowledgeable in the sight of Allah are likened to the level of the angels. Says one who has knowledge of the Bible: I will bring the throne before your eyes blink.

Al-Ghazaly explained, as quoted by Athiyah Al-Abrasyi in the book Ihya Ulumuddin Volume I page 25, the position of science and scholars or scholars. "A person who has knowledge and then works with that knowledge, then he is the one who is called great under this sky, like the sun that shines on others and illuminates himself, like musk oil whose smell is enjoyed by others and he himself is fragrant. Whoever works in the field of education, then in fact he has chosen an honourable and essential job, then he should maintain etiquette and manners in this task "(Al-Abrasy 1964).

K.H. Abd. Rahman Ambo Dalle believes that teachers must be reminded who will later teach students (santri) in Madrasas to spread Islamic education and its institutions. So that he, as the head of an educational institution in the Darud Da'wah Wal-Irsyad (DDI) environment, was appointed a teacher, where there is a Darud Da'wah Wal-Irsyad Madrasah there must be a teacher sent to teach at the Madrasa.

Abd. Rahman Fasih 1984 explained that K. H. Abd. Rahman Ambo Dalle when the DDI Branch Manager asked the teacher to be used in his fostered madrasa, then one of the students was appointed. However, without 
going through the training process first, it's just that if the santri were about to leave, they were required to face K. H. Abd first. Rahman Ambo Dalle to pray for (given a barakka). Meanwhile H. Iskandar explained that K. H. Abd. Rahman Ambo Dalle appointed teachers to teach at Madrasah only the students themselves, the higher-level students taught to the lower-level students. (Rahman 1984).

H. Iskandar 2004 explained that K. H. Abd. Rahman Ambo Dalle, when appointing teaching staff, does not always go through a training process but is appointed according to his discretion. However, those appointed as teachers have full responsibility to carry out their assigned teaching tasks (Iskandar 2004).

Manhaj Tarbiyah Al-Mutaalim K. H.

Abd. Rahman Ambo Dalle stated by $\mathrm{H}$. Muhammadeng that before leaving for teaching, he gave provisions:

1. Laheremmu Lawo, baten iya tu lawo (physically you are the one leaving, but in fact, I am the one leaving)

2. Appaguruko nasaba Puang Allah Ta'ala (Teach sincerely because of Allah)

3. Kurikulum (buku petunjuk) mengajar dan buku yang digunakan mengajar.

4. Menyuruh untuk mengajarkan banyak nyanyian kepada murid.

5. Mengangkat Mupatti untuk guru DDI. (Muhammadeng 2004).

Therefore, before the departure of the teacher who will be sent has been given mental provisions, filled with the belief that his departure is essentially not him but $\mathrm{K}$. $\mathrm{H}$. Abd. Rahman Ambo Dalle as a teacher who has broad and deep knowledge. This kind of mental filling gives impetus to prospective teachers that their arrival in teaching somewhere already has the same knowledge as the teacher's knowledge.

Once further, it is also a provision in the form of moral messages. The students who are sent in carry out their duties must be sincere. There is no lure, including wanting a high salary. Teachers who are sent are expected to teach sincerely without expecting a high salary or getting appreciation from others. In addition to the mental provisions given to the teachers who were sent, they have also been given teaching guidelines (curriculum) which are included in the teaching guidebooks. The teaching guide book is a book compiled by K. H. Abd. Rahman
Ambo Dalle, written in only two languages, namely Arabic and Bugis. Teachers who are sent to teach not only knowledge but are also recommended to teach songs, but the songs are songs that can inspire and encourage students to study harder and study Islam.

For the effectiveness and fluency of teaching, K. H. Abd. Rahman Ambo Dalle appointed Mupatti, a kind of supervisor or education supervisor who has the task of guiding, evaluating the implementation of the duties of teachers who sent to teach in an area, and even reporting to K. H. Abd. Rahman Ambo Dalle as leader of the Darud Da'wah Wal-Irsyad Organization (DDI) (Muhammadeng 2004)

K.H. Abd. Rahman Ambo Dalle is a diligent teacher. H. Muhammad Rasyid Rida explains that he is tireless in teaching anytime and anywhere, especially the children who accompany him, so he never escapes from books even though he is far away. In dealing with students (santri) it seems that it is never complicated or anger. His specialty is that he never discriminates against students (santri), and does not even discriminate between students and their biological children. (Ridha 2004).

\section{Manhaj Tarbiyah Al-Tullab}

Al-Tullab means demanding, seeking, asking, while Tholabul Ilmi means the seeker of knowledge, Tullab means student. So Manhaj Tarbiyah Al-Tullab is a method of educating, teaching students (Yunus t.th.).

In educating, you must have the right manhaj because it will be fatal for students if you choose the wrong method. Zakiah Daradjat 1995 explains, "Islamic education is meant to improve mental attitudes that will be manifested in deeds, both for their own needs and for the needs of others" (Daradjat 1995).

Manhaj teaching is significant to be applied in the educational environment if teaching in Madrasas or Schools. "The teaching method in question is a way of delivering learning materials to achieve the stated goals" (Usman 2002). The concept of Islamic education applies in educational institutions (such as Islamic Boarding Schools and Madrasas), then education and teaching must be applied. It means that students or students must be mentally corrected, and their brain knowledge must also be filled. 
Using the correct Manhaj by the teacher is of great benefit to students or students. Ibn Qayyim 691 said: "Indeed the merit of a pious person who wants to teach his knowledge is very significant because with the light of his knowledge he can bring people out of the dark tunnel of ignorance. Likewise, the benefits of teaching others knowledge are felt by other people who are learning and felt by the teacher. Teaching by using knowledge will be felt by students or students. It means that people who know, in this case, Manhaj (teaching method), are very influential on the acceleration of the transfer of knowledge from teachers (Ustadz) to students or students (Hasbullah 2001).

K.H. Abd. Rahman Ambo Dalle is seen as an educational figure consistent in implementing the correct Manhaj in the education system. It can even be said that $\mathrm{K}$. H. Abd. Rahman Ambo Dalle is very moderate in implementing the Manhaj of education in the educational institutions he leads, namely applying two Manhajs in a unified form between the Traditional and Modern Manhajs. Manhaj Tarbiyah Al-Tullab K.H.Abd. Rahman Ambo Dalle strongly emphasizes students to form morals, which can be seen in one of the discussions of his book entitled "Jaliyatu As-Syababi Volume II lessons 12 and 13", which discusses the manners that students must do in school and manners with the teacher. The contents of the book explain:

You must enter school at the appointed time and be polite to your teacher. The teacher is the person who educates you spiritually as your father educated your body, so it is obligatory for you to love, glorify and respect him because indeed your love for your teacher is obligatory upon you to obey his orders. Please do not raise your voice above his voice, and do not look at him with more glaring eyes. That reduces politeness in terms of morals.

According to Abd. Halim, that K. H. Abd. Rahman Ambo Dalle always emphasized that to uphold moral values, students must obey and carry out excellent and noble character. If he encounters students or students who are not polite at school, especially to his teacher or Ustadz, then the student is reprimanded and given guidance (Halim 2004).

K.H. Abd. Rahman Ambo Dalle in Manhaj Tarbiyah At-Tullab always emphasizes studying hard, both at school and home, even studying wherever they are. H. M. Arief Fasieh 2004 explained that K. H. Abd. Rahman Ambo Dalle, in guiding students to be able to study anytime and anywhere, the most recommended lesson even required is to study Arabic lessons. Because language learning is a source of knowledge in Islam, it must be studied and known by the students. It can be proven by the book or books compiled by K. H. Abd. Rahman Ambo Dalle only consists of two languages, namely Arabic and Bugis. (Arief 2004)

One exciting thing characterizes Manhaj Tarbiyah Al-Tullab K. H. Abd. Rahman Ambo Dalle, where students are prohibited from taking state equality exams. K.H.Abd. Rahman Ambo Dalle in Manhaj Tarbiyah Al-Tullab that there are several things that students should not do while studying, among these characteristics include:

1. No smoking.

2. It is forbidden to nail length.

3 . Do not be sleepy while studying.

4. It is forbidden to lean on the chin.

5. It is forbidden to erect the knee.

6. Prohibited long hair (male). (Halim 2004)

The things mentioned above are constantly monitored by K. H. Abd. Rahman Ambo Dalle as the leader of the Islamic Boarding School. If anyone is found to be in violation, they will be reprimanded. Abd. Halim, K 2004 explained that K. H. Abd. Rahman Ambo Dalle, in admonishing students, never applied punishment, never corporal law, except for his children. (Halim 2004)

\section{Criticism of Manhaj Tarbiyah KH Abd. Rahman Ambo Dalle}

Manhaj Tarbiyah K. H. Abd. Rahman Ambo Dalle, some Manhajs are still excellent and suitable in current conditions. Besides that, there may be Manhajs that are lacking and even not by current conditions. For more details, it can be criticized the Manhaj used as discussed in the previous chapter.

\section{Manhaj Tarbiyah Al-Akaid}

Manhaj teaching Aqaid (Aqidah) K. H. Abd. Rahman Ambo Dalle is still possible to apply and is suitable for current conditions. Manhaj was teaching Muhadara and Muhawarah, which are commonly applied, especially the teaching of halaqah (sorongan) 
in mosques and in the classroom, which is essentially questions and answers and discussions by the teaching methods adopted in modern times today. Teaching methods, both conventional and non-conventional, also require active students, which is commonly known as the Equally Active Learning Method (CBSA); This CBSA method or system requires both teachers and students to be active (Usman 2002).

K.H.Abd. Rahman Ambo Dalle in Manhaj Aqaid uses psychological analysis, meaning that students or santri are taught based on their level of intellectual development. Madrasah Diniyah/Ibtidaiyah level students are given easy lessons in memorization and habituation. In contrast, at the middle and high levels, they have increased in teaching analysis. This is explained in Q.S. 2:286. Allah does not burden a person but according to his ability. The hadith also explains that make it easy and do not make it difficult, and be happy and do not make it difficult (Muslim t.th).

The above verse and hadith mean that the teacher (Ustadz), in providing teaching, must pay attention to and adjust the intelligence level of the child; the goal is that students (santri) can quickly receive, process, and store the subject matter given to him.

\section{Manhaj Tarbiyah Al-Akhlak}

According to K. H. Abd. Rahman Ambo

Dalle, Morals is urgent to know, practised by humans. The morals in question are morals that are classified as good morals (mahmudah). However, it is not easy to practice these morals because they must be instilled in humans since childhood to proceed through the correct Manhaj.

According to K. H. Abd. Rahman Ambo Dalle in Manhaj, humans must be taught at least an outline of morals.

a. Morals in general.

b. Morals in particular.

c. Morals more specifically.

Morals that need to be given to humans are Allah SWT's morals, the Prophet Muhammad's morals, and morals to religion. In essence, this morality is nothing but the procedure of worshipping Allah SWT. So, since childhood, humans must be taught to worship Allah SWT. The basis of this Manhaj is following the word of Allah SWT. in the Qur'an Q.S. 98:5.
Worshipping Allah is a moral towards Allah SWT. Worship shows obedience to carry out commands such as prayer and zakat so that this is the straight path.

Morals towards parents following the above verse are commanded to do good, respect them and are prohibited from expressing harsh words that offend. The morality of fellow human beings towards friends is highly recommended by the Prophet Muhammad. His saying reads: "Fellow believers are like a house; each other strengthens each other". (Muslim t.th). This hadith shows how important it is to develop morals towards others and those closest to the family, especially to two parents. Also, part of morals that is no less important is taking care of oneself; self-care is meant to maintain all the body's organs so that they remain perfect, not sick, be honest and so on. Manhaj Tarbiyah Akhlak, as described above, still needs to be continued, and this is still very relevant to the current conditions to be applied.

\section{Manhaj Tarbiyah Al-Muta'allim}

The teacher in an educational institution is one of the most critical factors because the teacher functions as a source of knowledge in charge of transferring knowledge to students. With this, the teacher's task is cumbersome but also very noble. K.H.Abd. Rahman Ambo Dalle is an educator figure who has succeeded in developing Islamic educational institutions and producing teachers at the institutions he leads. Efforts to print or appoint teachers according to observations that still need to be preserved because they are still suitable for current conditions such as:

a. Mental provision.

b. The need for teaching guidelines and textbooks.

c. Learn singing.

d. Appoint Mupatti (supervisor) in the field of education.

The teacher appointed by K. H. Abd. Rahman Ambo Dalle was first given mental training before serving. The aim was to motivate so that later in carrying out his duties, he could be enthusiastic. Books are a storehouse of knowledge, and reading is the key. It is what inspired the thinking of $\mathrm{K}$. $\mathrm{H}$. Abd. Rahman Ambo Dalle. Every teacher sent is given written guidelines to be guided in 
teaching, especially books that are sources of reference in teaching.

Singing is also the essential aspect to be given to students or santri, so teachers must be taught singing, but the songs that are taught are songs that can be a motivation for learning and songs that can be entertainment that soothes the hearts of students. Mupatti acts as a supervisor for teachers assigned to teach. K.H. Abd. Rahman Ambo Dalle appointed Mupatti as supervisor of the course of education. Besides that, he was also tasked with guiding teachers when they had difficulties carrying out their teaching tasks.

On the other hand, there may be some that are not following today's current natural conditions, including:

1. Teaching by relying on sincerity

2. Appointing teachers who do not have teaching skills.

Teaching by relying on sincerity is incompatible with current conditions because people who teach sincerely do not demand material values. While currently in a material condition, teachers need adequate salaries to support the smooth implementation of teaching tasks. Another thing is that teachers who have never been equipped with the knowledge and skills to teach are also in conflict with current conditions. The modern view requires that the teacher who will teach must be professional, that is, have the skills and teaching skills supported by the teacher's educational background.

\section{Manhaj Tarbiyah Al-Tullab}

Students who study must obey the various rules in the Madrasa (School) where they gain knowledge. In carrying out his Manhaj At-Tullab, K. H. Abd. Rahman Ambo Dalle runs a blend of traditional and modern Manhaj so that students have a high willingness to learn. Specifically, K. H. Abd. Rahman Ambo Dalle strongly emphasizes that students can master the language because language is the primary key in understanding science. At that time, the most emphasized languages were Arabic and Bugis. The reason is that Arabic is the language used to understand religion, while Bugis is a language that the people of South Sulawesi easily understand. Students should respect the teacher (Ustadz) who teaches them, and students must be disciplined and learn.
Therefore K. H. Abd. Rahman Ambo Dalle in making students disciplined by issuing rules to be obeyed by students, including the rules that students must obey are:
a. No smoking.
b. Long nails are prohibited.
c. Do not fall asleep while studying.
d. It is forbidden to bend the knees.
e. Hair length is prohibited.
f. In speaking must be clear.

The prohibition above is part of the Manhaj Al-Tullab K. H. Abd. Rahman Ambo Dalle, which is still suitable for the current situation. Most educational institutions such as Madrasas (schools) are still implementing it. However, Manhaj Al-Tullab K. H. Abd. Rahman Ambo Dalle is not entirely suited to the current conditions. There is only one manhaj that is not appropriate today by the author: "Santri or students are prohibited from taking the State Equality Examination". According to him, students do not need to pursue a state diploma. Even though students have a state diploma, if they are not intelligent, it is also useless.

\section{CLOSING}

K.H.Abd. Rahman Ambo Dalle was born from UjungngE Village, Tana Sitolo District, Wajo Regency, in 1900. Thanks to his perseverance and expertise in studying, he became a great and famous Ulama. Ulama who have been considered successful in developing Islamic educational institutions in Indonesia through Manhaj Tarbiyah AlIslamiyah. It is considered successful because it has blended two Manhajs, namely the traditional Manhaj and the Modern Manhaj. Manhaj Tarbiyah Al-Islamiyah K. H. Abd. Rahman Ambo Dalle in the concept of its application is still by current conditions; however, it is also seen that some are not under current conditions. To all educators, especially Islamic education, it is hoped that they can imitate Manhaj Tarbiyah K. H. Abd. Rahman Ambo Dalle. To the coaches of educational institutions, especially Islamic educational institutions, they can learn Manhaj Tarbiyah K. H. Abd. Rahman Ambo Dalle to be applied in the educational institution he fosters. 


\section{ACKNOWLEDGEMENT}

The author would like to thank Dr. H. Saprillah, M.Si, Head of Makassar Religious Research and Development Agency, and AlQalam Redakt ur Board Member for accepting this article.

\section{REFERENCES}

As-Suyuty, Jalaluddin Abdurrahman bin Abi Bakar. 1968 Al-Jamius Shagier, BilQahirah, Darul Katibi Arabi Litthibati Wan-Nasyir.

Al-Abrasyi, Mohd. Athiyah. 1964. Attabiyah Al-Islamiyah. al-Madarul Qaumiyah Littibaati Wan Nasyir.

Arikunto, Suharmisi. 1995. Manajemen Penelitian. Jakarta; Rineka cipta.

Al-Attas, Naquib, M. Syaed. 2003. The educational Philosophy and Practice, Alih bahasa: Hamid Fahmi, dkk. Dengan judul Filsafat Pendidikan Islam. Bandung; Mizan.

Al-Ghazaly, Muhammad, Hamid Muhammad, t.th. Ihya Ulumuddin. Libanon, Darul Ma'rifah Littibaati Wan Nasyir.

Abdullah Taufik (ed). 1989. Metodologi Penelitian Agama Suatu Pengantar. Yogyakarta: Tiarawacana.

Azra, Azyumardi. 2000. Pendidikan Islam Tradisi dan Modernisasi Menuju Milinium Baru. Jakarta: Logos Wacana Ilmu.

Arrosi Arman. 1993. Pengembaraan Batin Bung Karno. Bandung; PT. Remaja Rosdakarya.

Arsyad, Azhar, dkk. 2003. Ke-DDI-an sejarah dan Pandangan Atas Isu-isu Kontemporer. Makassar: LKPMP-DDI Kerjasama The Asien Fondation.

Departemen Agama RI. 1995. Al-qur'an dan Tejemahannya. Jakarta: Yayasan Penyelenggara Penterjemah/Penafsir Al-Qur'an.

Dijk, Cornelis Van. 1995. "Rebillion Under The Banner Of islam (The Darul Islam In Indonesia)", dengan Judul: Darul Islam; Sebuah Pemberontakan. Pustaka Graffti.
Fajri, Zul Em, dkk. t.th. Kamus Lengkap Bahasa Indonesia t.tp.: Dipa Publiser.

Hasan Al-Hijazy, Hasan Bin Ali. 2001. AlFajrut Tarbawy Inda Ibnu Qayyim, alih Bahasa: Muzaidi Hasbullah, Dengan Judul: Manhaj Pendidikan Ilmu Qayyim. Jakarta; Pustaka Al-Kautsar.

Langgulung, Hasan. 1995. Beberapa Pemikiran Tentang Pendidikan Islam. Bandung: PT. Al- Ma'arif.

Mastuhu. 1999. Memberdayakan Sistem Pendidikan Islam. Jakarta: Logos Wacana Ilmu.

Muslim Bin Hajja al-Qusyairy. t.th. An Nasabuni, Shahih Muslim Juz 1 - 4. Semarang Indonesia, Maktabah WaMuthbaah Toha Putra.

Munawwir, Ahmad Wirson. 1997. Kamus Arab-Indonesia. Cetakan XIV: Yogyakarta; Pustaka Progressif.

Noer Ali, Herry Munzir. 2000. Watak Pendidikan Islam. Jakarta; Friska Agung Insani.

Qardhawi, Yusuf. 2003. Al-Aqlu Wal-Islam Fi-Qur'anil Karim, Alih Bahasa: Abdul Hayyie, dkk. Dengan Judul: Al-Qur'an Berbicara tentang Akal dan Ilmu Pengetahuan. Jakarta; Gema Insani Press.

Quthb, Muhammad. 1995. Alih Bahasa: Sulaiman Harun, Dengan Judul: Sistem Pendidikan Islam. Bandung; PT. AlMa'arif.

Rahim, Husni. 2001. Arah Baru Pendidikan Islam Di Indonesi. Jakarta; Logos Wacana Ilmu.

Saleh Abbdullah, Abdurrahman. 1990. Educational Theory; a Que'anic Outlook, Alih Bahasa: Arifin, Dengan Judul: Teori Pendidikan Menurut AlQur'an. Jakarta; Rineka Cipta.

Tungke, Wanua. 2002. A. Kahar Muzakkar Masih Hidup (Sebuah Misteri), Makassar; Pustaka Refleksi.

Tafsir, Ahmad. 1992. Ilmu Pendidikan Persfektif Pendidikan. Bandung; PT. Remaja Rosdakarya.

Zuhairini, dkk. 1992. Sejarah Pendidikan Islam. Jakarta; Bumi Aksara. 
